\title{
DISTRIBUTION AND BIOLOGICAL FEATURES OF THE AFRICAN ARMOURED SEAROBIN, PERISTEDION CATAPHRACTUM (ACTINOPTERYGII: SCORPAENIFORMES: PERISTEDIIDAE), OFF THE SOUTHERN COASTS OF SICILY (MEDITERRANEAN SEA)
}

\author{
Teresa BOTTARI ${ }^{1 *}$, Mark DIMECH ${ }^{2}$, Giandomenico NARDONE ${ }^{3}$, Paola RINELLI ${ }^{1}$, \\ and Sergio RAGONESE ${ }^{3}$ \\ ${ }^{1}$ Institute for Coastal Marine Environment (IAMC) National Research Council (CNR), Spianata S. Raineri, \\ 8698122 Messina, Italy \\ ${ }^{2}$ Department of Biology, University of Malta, Msida, Malta \\ ${ }^{3}$ Institute for Coastal Marine Environment IAMC National Research Council (CNR), Via L. Vaccara, \\ 6191026 Mazara del Vallo (TP), Italy
}

Bottari T., Dimech M.,Nardone G., Rinelli P., Ragonese S. 2010. Distribution and biological features of the African armoured searobin, Peristedion cataphractum (Actinopterygii: Scorpaeniformes: Peristediidae), off the southern coasts of Sicily (Mediterranean Sea). Acta Ichthyol. Piscat. 40 (2): $113-127$.

Background. The African armoured searobin, Peristedion cataphractum, is a medium sized, gregarious, demersal fish distributed in the Eastern Atlantic and the Mediterranean Sea. Once considered abundant in all the Mediterranean basins, nowadays the species represents an appreciable by-catch of bottom trawlers only in limited areas. The aim of the present was to perform a synthetic analysis of the distribution, abundance, and biological traits of this poorly investigated species.

Materials and Methods. This paper is based on the information recovered from the available "grey" data sources as well as on new original data gathered in 13 experimental bottom trawl surveys carried out off the southern coasts of Sicily from 1994 to 2005. Data recovering and processing regarded distribution, abundance, sex ratio, maturity condition, length structure, and its evolution in time, and growth estimation.

Results. The specimens of $P$. cataphractum were present in all investigated areas, with highest abundance in the eastern grounds, between 50 and $800 \mathrm{~m}$, showing a preference for the upper slope $(201-500 \mathrm{~m})$. Sexed specimens were almost equally distributed between females and males (overall sex ratio, Sr, between 0.49 and 0.54 ). Recruits (80-130 mm total length, TL) occurred continuously from September to March, with a peak from late December thru March. The size at onset of sexual maturity $\left(L_{m}\right.$ at 50\%) was achieved at 191 and $212 \mathrm{~mm}$ for females and males, respectively. Growth was evaluated (sex combined) by applying length based methods (LBMs); up five significant modal components were evidenced, the first 2-3 well distinguished. Two sets of the special von Bertalanffy function were derived reflecting juveniles/adult $\left(L_{\infty}=380 \mathrm{~mm}, \mathrm{Ky}^{-1}=0.34\right.$ and $\left.t_{0 y}=-0.76\right)$ and adults $\left(L_{\infty}=313 \mathrm{~mm}, \mathrm{Ky}^{-1}=0.28\right.$ and $\left.t_{0 y}=-0.99\right)$ growth trajectories.

Conclusion. The review performed in the frames of the presently reported study helped to propose a plausible life history of the investigated stock.

Keywords: African armoured searobin, Peristedion cataphractum, bottom trawl surveys, distribution, biological traits, growth, Mediterranean Sea, Sicily

\section{INTRODUCTION}

The African armoured searobin, Peristedion cataphractum L., 1758, which derives its specific name from the Greek cataphractos (covered with an armour), is one among the twenty-two valid species of its genus distributed in tropical and sub tropical deep waters worldwide (Heemstra 1975, Hureau 1986, Myers et al. 2008, Froese and Pauly 2009). The only representative of its genus in the Mediterranean Sea (Quignard and Tomasini 2000), the African armoured searobin is a medium sized (usually 200-300 mm, maximum $400 \mathrm{~mm} \mathrm{TL}$ ), gregarious, demersal fish distributed in the Eastern Atlantic (from the British Isles to Angola) and the Mediterranean Sea. It occurs preferably on muddy bottoms of the shelf, $30-200 \mathrm{~m}$,

\footnotetext{
* Correspondence: Dr. Teresa Bottari, Istituto per l'Ambiente Marino Costiero del CNR, Spianata San Raineri, 86-98122 Messina, Italia, phone: +3990 669 007, fax: +3990669003, e-mail: teresa.bottari@iamc.cnr.it
} 
and upper slope, 201-700 m, occasionally on deeper (848 m) waters (Bauchot and Pras 1980, Mytilineou et al. 2004, Froese and Pauly 2009). Close to triglids (to which the species was included for long time), the African armoured searobin is now assigned to the family Peristedidae, given the heavy scales covering almost all the body, the long "rostra" (two expansions of the preorbital bones forming a sort of shovel), only two free rays in the pectoral fins, tufts of mandibular tactile barbels, and the lack of tongue. Beside some variability in body proportions (such as the longer rostrum in juveniles males; Muñoz-Chápuli and Blasco-Ruiz 1980), clear evidences of sexual dimorphism are limited in the adult specimens (larger than 140-150 mm) mainly regarding the thin extensions of the first six rays of the 1st dorsal fin and a darkish band on the anal fin in males (Tortonese 1975, Muñoz Chápuli and Blasco Ruiz 1981, Pizzicori et al. 1995, Pizzicori unpublished*).

Although the African armoured searobin possessed swim bladder and able to swim in the water column (Bini 1969), it likely prefers to stay and walk on the bottom with its free pectoral fin rays. It uses the rostrum to root in the sediment since infaunal organisms like Crustaceans (mainly Mysidacea, such as Lophogaster sp.) and Mollusca were common dietary items. Once considered abundant in all the Mediterranean basins (Baudorel 1948, Bini 1969, Tortonese 1975), nowadays the species represents an appreciable by-catch of bottom trawlers only in limited areas. As other congeners (cf. Lekshmy-Nair et al. 1989), the meat has been quite appreciated since long time (Baudorel 1948) and recipe are presented in cook books, but since the handling difficulties, the species is general found only in local market. Scanty published information exists on this species (Table 1): eggs and larvae (Doderlein 1879, Emery 1886, Spartà 1947), general features (Tortonese 1975) and growth estimations (Mytilineou et al. 2004). As concerns the area off the southern coasts of Sicily, the African armoured searobin was historically considered as a common widespread findings and most recurrent catch (Bourgois and Farina 1961, Arena unpublished ${ }^{* *}$ ), whereas Pizzicori et al. (1995), highlighted higher concentration in the eastern side of the area. Only a preliminary study of the Sicilian stock is available after both grey (Pizzicori unpublished*) and published (Pizzicori et al. 1995) contributes. Aim of the present study is performing a synthetic analysis of the distribution, abundance and biological traits of this poorly investigated species by using both recovered grey data and direct collected information.

\section{MATERIAL AND METHODS}

Study area and sampling design. The study area covers about $100000 \mathrm{~km}^{2}$ and is located between the southern coasts of Sicily and the northern coasts of Tunisia and Libya (Fig. 1). Morphologically, it comprises different morphologic units: continental shelf and slope, seamounts ("guyots"), and "banks" (Arena unpublished**). The slope shape is extremely irregular, incised by many canyons, trenches, and steep declines. Hydrological pattern of the depth interval explored by both commercial fisheries and trawl surveys (10-800 m), three main water layers are traditionally recognized (according to Sardà et al. 2004):

a) The Atlantic (AW; down to $50-100 \mathrm{~m}$ or to $150-250 \mathrm{~m}$, depending on locations) with a minimum water temperature of $14-15^{\circ} \mathrm{C}$ in winter;

b) The Levantine ( $\mathrm{LW}$; down to $500-700 \mathrm{~m}$ ), where the temperature goes down to about $13-14{ }^{\circ} \mathrm{C}$ ); and

c) A deep transitional layer (below $600-700 \mathrm{~m} ; 12.8^{\circ} \mathrm{C}$ ).

The most striking recent modification consists in the invasion of the so-called Transitional Eastern Mediterranean Deep water (TEMDW or EMTW), a slightly warmer $\left(13.5^{\circ} \mathrm{C}\right)$ and much denser body of water, originated some years ago in the Eastern Mediterranean (Briand 2000). Average sea water temperature at the bottom, gathered by minilog during the most recent surveys (Ragonese et al. 2008), denoted homogeneity $\left(13.8-14.8^{\circ} \mathrm{C}\right)$ at bottoms below $100 \mathrm{~m}$, whereas a positive $\mathrm{W}-\mathrm{E}$ gradient characterized the surface layers.

Data source and samples processing. Distribution, abundance, and biological traits of the African armoured searobin were based on the analysis of both official and grey literature information. In particular, data were recovered from old archives or unpublished report (Pizzicori unpublished*), or directly gathered within bottom trawl surveys carried out between 1994 and 2005 (Table 2) off the southern coasts of Sicily (Levi et al. 1998). A depth-stratified sampling design was adopted; five depth strata (limits in meters) were identified: 10-50 (code A), 50-100 (B), 100-200 (C), 200-500 (D), and 500-800 (E). The sampling hauls were randomly allocated within the strata according to an area-proportional criterion (Table 2).

Samplings were always been conducted with the same vessel, a commercial stern trawler harbored in Mazara, the M/T SANT' ANNA (32.2 m length overall; powered with a $736-\mathrm{kW}$ engine). The gear employs rectangular wooden boards and $20 \mathrm{~mm}$-diamond stretched mesh size codend; the vertical opening is ca. $0.6-1.3 \mathrm{~m}$.

Daytime (30 minutes before dawn and after dusk) hauls lasting $0.5-1 \mathrm{~h}$ was performed. The haul catch, once on the deck, was sorted for the African armoured searobin and overall abundance in weight and number recorded on board. The corresponding biological material was properly packed in plastic boxes, and frozen at $-40{ }^{\circ} \mathrm{C}$. In laboratory, each sampled specimen was defrosted overnight, measured (TL, mm), and dissected in order to expose the internal body cavity and evaluate macroscopically (i.e., by naked eye) the gender (females, males, and unsexed). Specimens were classified in five macroscopic maturity

* Pizzicori P. 1993. Determinazione dell'età, riproduzione e distribuzione nel canale di Sicilia del pesce forca (Peristedion cataphractum L, 1758). [Age estimation, reproduction and distribution of the Africal armoured searobin (Peristedion cataphractum L, 1758).] (unpublished) Dissertation, University of La Sapienza, Roma, Italy. [In Italian.] ** Arena P. 1985. Studio sulla possibilità di razionalizzare e rendere più produttiva la pesca a strascico nel Canale di Sicilia e nel Mediterraneo Centro - Meridionale. ESPI, Palermo[On the possibility to razionalize and make more productive trawling in the Strait of Sicily and in the South-Central Mediterranean Sea] (mimeo). [In Italian.] 
Synopsis of the avialble information concerning Peristedion cataphractum

\begin{tabular}{|c|c|c|}
\hline Parameter & Value & Reference \\
\hline Egg diameter [mm] & 1.52 & Spartà 1947 \\
\hline Embryonic span [days] & $2-3$ & Spartà 1947 \\
\hline Hatching size $[\mathrm{mm}]$ & 4 & Spartà 1947 \\
\hline Duration of larval period [months] & Few & Spartà 1947 \\
\hline $\begin{array}{l}\text { Length of pelagic to benthic transition stage } \\
\text { (trigloid or littoral) [mm] }\end{array}$ & $40-70$ & $\begin{array}{l}\text { Doderlein } 1879 \\
\text { Emery } 1886\end{array}$ \\
\hline $\begin{array}{l}\text { Length of post larval stage } \\
\text { (scorpenoid or pelagic) [mm] }\end{array}$ & 115 & Emery 1886 \\
\hline \multirow{2}{*}{ Depth range $[\mathrm{m}]$} & $49-733$ & Pizzicori et al. 1995 \\
\hline & down to 800 & Froese and Pauly 2009 \\
\hline Preferential depth range $[\mathrm{m}]$ & $200-500$ & Pizzicori et al. 1995 \\
\hline Recruitment season (size range) $[\mathrm{mm}]$ & $\begin{array}{l}\text { Start in Summer }(45-52) \text { peak in } \\
\text { autumn }(65-75) \text { completed in winter } \\
(84-103)\end{array}$ & Pizzicori et al. 1995 \\
\hline $\begin{array}{l}\text { Juveniles/youngest of the year } \\
(\mathrm{TL}=90-150 \mathrm{~mm}) \text { main location }\end{array}$ & 300-400 m NW Malta Island & Pizzicori et al. 1995 \\
\hline Maximum size range $[\mathrm{mm}]$ & $310-400$ & Pizzicori et al. 1995 \\
\hline Sex ratio $[F / M+F]$ & 0.54 & Pizzicori et al. 1995 \\
\hline GI, Gonadosomatic Index (F; GW/EW; \%) & $\begin{array}{l}0.36 \text { (winter)-0.55 (autumn) } \\
3.22 \text { (spring)-7.42 (summer) }\end{array}$ & Pizzicori et al. 1995 \\
\hline Max GI at size class (F) & $146 \%$ at $270 \mathrm{~mm}$ & Pizzicori et al. 1995 \\
\hline \multirow[t]{2}{*}{ Gonads maturing/ripening } & Spring & $\begin{array}{c}\text { Tortonese } 1975 \\
\text { Pizzicori et al. } 1995\end{array}$ \\
\hline & Summer & Tortonese 1975 \\
\hline \multirow[t]{2}{*}{ Spawning } & Summer & Pizzicori et al. 1995 \\
\hline & Summer-Autumn & Mytilineou et al. 2004 \\
\hline Minimum size at sexual maturity $[\mathrm{F} ; \mathrm{mm}]$ & 220 & Pizzicori et al. 1995 \\
\hline Adulthood size in males [mm] & $>150$ & Pizzicori et al. 1995 \\
\hline \multirow{3}{*}{$L-W$ relation $(\mathrm{F})$} & $b \geq 3 ; \max b=3.4$, in spring & Pizzicori et al. 1995 \\
\hline & $b=3.03$ & Merella et al. 1997 \\
\hline & $b=2.97$ & Filiz and Bilge 2004 \\
\hline LR (rostrum excluded) L relation & Linear & Pizzicori et al. 1995 \\
\hline Growth, special VBGF; Eastern Ionian Sea & $\begin{array}{c}L_{\infty}=384 \mathrm{~mm} ; \mathrm{Ky}^{-1}=0.182 \\
t_{0}=-1.36 y\end{array}$ & Mytilineou et al. 2004 \\
\hline
\end{tabular}

$\mathrm{F}=$ females; $\mathrm{M}=$ males; $\mathrm{GW}=$ gonad weight; $\mathrm{EW}=$ eviscerated body weight; $L-W=$ length-weight; $b=$ allometric coefficient; $\mathrm{LR}=$ rostrum excluded body length; $L=$ total body length; $L_{\infty}=$ asymptotic total length; $\mathrm{Ky}^{-1}$ : growth curvature parameter; $t_{0}$ : theoretical age when total length of fish is zero.

stages as follows: 1st-immature; 2nd-immature/developing or recovering; 3rd-maturing; 4th-fully mature; and 5th — spent or resting (Holden and Raitt 1974).

Data recovering and processing. Data recovering (1994-1998) and processing (2000-2005) regarded distribution, abundance, sex ratio, maturity condition, length structure, and its evolution in time, and growth estimation.

Abundance Index (AI), mean Density Index (DI $=n \cdot \mathrm{km}^{-2}$; $n$ : number of specimens) and Biomass Index $\left(\mathrm{BI}=\mathrm{kg} \cdot \mathrm{km}^{-2}\right)$, were estimated (for each stratum and overall area) according to the swept-area principle (Gunderson 1993). Frequency of occurrence $(f)$ was also computed as percentage of positive hauls (presence of at least 1 specimen). The temporal correlation in AI was evaluated $(P<0.05)$ by computing the Spearman non-parametric rank coefficient $\left(r_{s}\right)$ after $\log _{\mathrm{e}}$ transformation.

The DI by haul were interpolated and mapped for the whole population in order to get an idea of stock spatial heterogeneity. In particular, the GIS software ArcMap ${ }^{\mathrm{TM}} 9.0$ (ESRI, Environmental Systems Research Institute Inc. 2004) was used to implement an "exact interpolator" procedure (IDW, Inverse Distance Weighting) to render back the exact value (or real value) in every sample site of the studied area and supply an estimation based on the average distance weighting for the other zones of the studied area. 
The relation between length and depth was also investigated. Minimum, maximum, and median lengths were calculated by depth interval (50 meters each) and graphically represented by box plots. To test the correlation between median length and depth, a Spearman test was applied.

The sex ratio (Sr), overall and by length class, was defined as the proportion of females $(F)$ on the total sexed individuals $(F+M)$. For the African armoured searobin, $\mathrm{Sr}$ around 0.5 is expected (Pizzicori et al. 1995, Mytilineou et al. 2004), hence data were not arc-sin transformed and variance was computed as follows:

$$
\operatorname{Var}(S r)=\sqrt{\frac{S r \cdot(1-S r)}{(F+M)}}
$$

The significance of the difference between the estimated and expected $\mathrm{Sr}$ were evaluated according to a $\chi^{2}$ test (with 1 degree of freedom).

Maturity structure was analyzed according to the box plot representation (medians by maturity stages), whereas a "size at the onset of sexual maturity" (SOM), herein defined as $L_{m}$, was derived according to the logistic approach;

$$
p_{a k}=\frac{1}{1+\exp -g \cdot\left(L_{k}-L m_{50 \%}\right)}
$$

where $p_{a k}$ represents the proportion of the mature/adults specimens (from 2 nd to 5 th stage) in length class $k, g$ is the steepness parameter, and $L_{m 50 \%}$ denotes the $L_{m}$ at $50 \%$.
A simple non-weighed least square regression was implemented as fitting procedure.

As concerns the length based analysis, individual lengths were combined by survey-time period in $10 \mathrm{~mm}$ class width and the resulting length frequency distribution (LFD) derived and converted in "FAO-ICLARM Stock Assessment Tools" (FiSAT-II; Gayanilo et al. 2005) and LFDA 5 (Hoggarth et al. 2006) files.

The published growth parameters (Pizzicori et al. 1995, Mytilineou et al. 2004) were referred to sex combined, hence $F+\mathrm{M}+$ Unsexed LFD were employed thru the contribute. To get an idea of the likely incidence of the sexual dimorphism in LFD shape and likely growth differential, a Kolmogorov-Smirnov (K-S) test was applied on the surveys gathered between 2000-2005 (where sexes were directly registered). The $\mathrm{K}-\mathrm{S}$ test revealed significant $(P<0.05)$ sex effect only in the last year; consequently, sex combined LFD were further maintained for growth analysis.

Regards the direct LFD fit, a proper standard chronological time $(0<t<1$ plus 1 for successive years) was assigned to each LFD on the base of the LFDA 5 procedure (days elapsed from January 1 to median survey day/365 days). Within FiSAT II, the LFD were firstly analyzed to get an estimate of $L_{\text {max }}$, based on the theory of extreme values and independent of any deterministic growth model (Formacion et al. 1991). Secondly, the normal components of LFD were individuated (MPA proce-

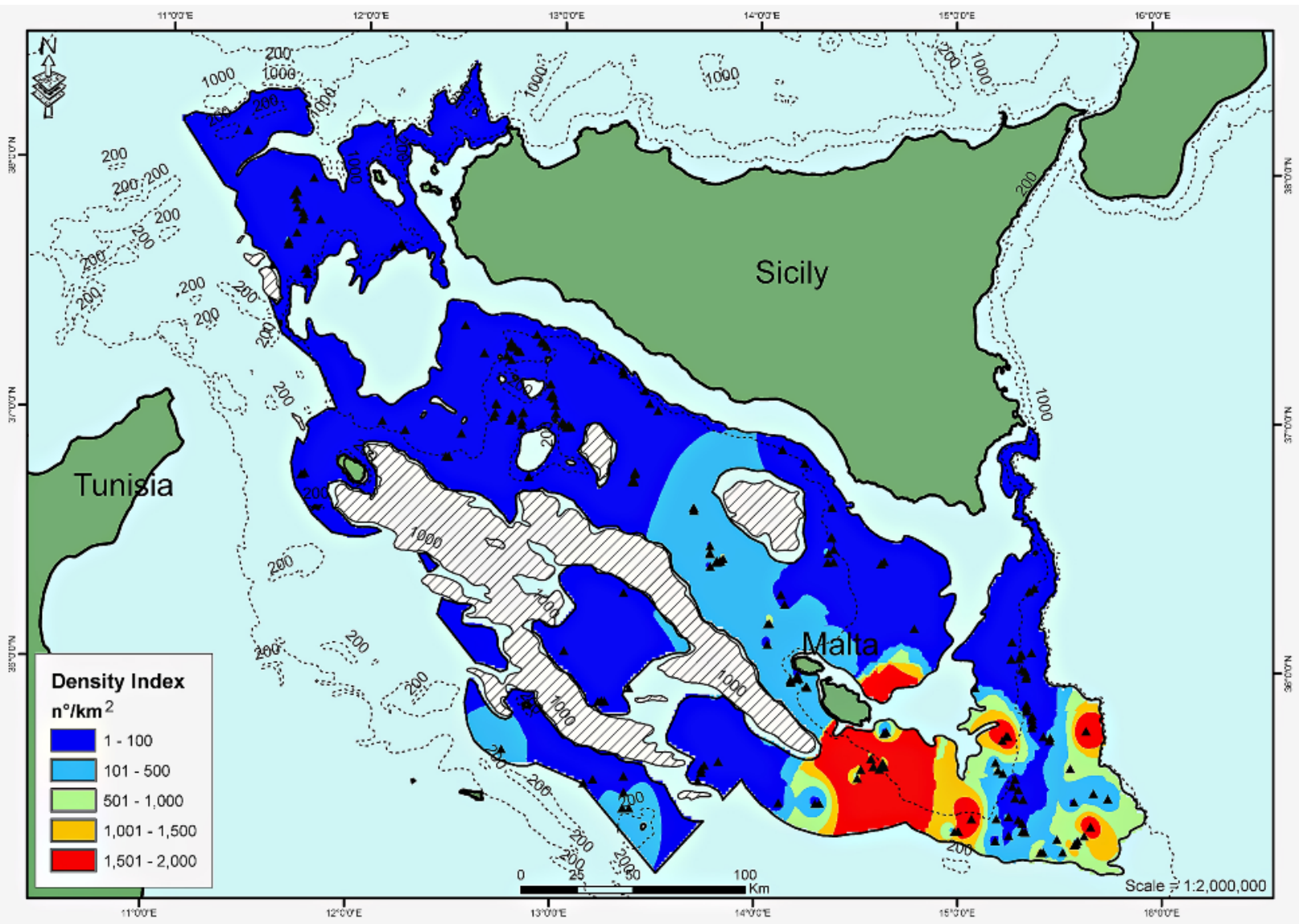

Fig. 1. The study area off the southern coasts of Sicily; spatial representation of the Density Index $\left(\mathrm{DI}=n \cdot \mathrm{km}^{-2}\right)$; of Peristedion cataphractum 
dures in FiSAT) following the method of Bhattacharya (1967); in particular, the LFD were analyzed to figure out the Representative-Well discriminated (RWd) groups, herein defined as those including an arbitrarily fraction of sample size (at least $10 \%$ in the specific case) and with a separation index, SI, higher than 2.1 ( 2 is the minimum requirement to allow an objective separation of two adjacent groups; Rosenberg and Beddington, 1988). Smoothing $(\times 3)$ was performed only when observed LFD presented a high irregular shape.

A putative age (years) was assigned at each groups on the base of an overall interpretation of the species biological information (literature and ancillary results derived in the present contribute). The great Mean modal lengths by age class, and corresponding standard error, of the RWd were hence tabulated.

The von Bertalanffy Growth Function (VBGF) was fit to the size at age data derived after the Bhattacharya application in order to identify objective seed values to be used within the LFDA 5 package; in particular, the software allows exploring the suitability of both a) non seasonal-special (3 parameters; Pauly 1984) and b) seasonal (5 parameters; Hoenig and Hanumara 1982) VBGF (see below).

$$
L_{t}=L_{\infty}\left[1-\exp -K\left(t-t_{0}\right)\right]
$$

where $L_{t}$ is the length at age $t, L_{\infty}$ is the maximum (asymptotic) length, $K$ is a measure of the growth rate (the rate at which $L_{\infty}$ is approached) and $t_{o}$ is the theoretical age at zero length. It is worth remarking that two scenarios have been proposed in fisheries literature for the relations between $L_{\infty}$ and $L_{\max }$ : i.e., $L_{\infty} / L_{\max } \sim 1.05$ (for fish not exceeding $500 \mathrm{~mm}$; Pauly 1984) and $L_{\infty} / L_{\max }<1$ (considering $L_{\infty}$ under a probability density function, pdf, criterion; Francis 1995).

The seasonal parameterization of the VBGF was:

$$
L_{t}=L_{\infty} \cdot\left\{1-\exp -\left[\left(K \cdot\left(t-t_{0}\right)-\left(\left(\frac{C \cdot K}{2 \pi}\right) \cdot \sin \left(2 \pi \cdot\left(t-t_{s}\right)\right)\right)\right]\right\}\right.
$$

where $L_{t}, L_{\infty}, K$, and $t_{0}$ are as above, and $C$ and $t_{s}$ fix the amplitude and position of the seasonality, respectively; the $t_{s}$ parameter is related to the moment in which growth starts slowing down and is related to the Winter Point by WP $=t_{s}+0.5$ (Pauly 1984).

The Shepherd's Length Composition Analysis (SLCA, Shepherd 1987; special VBGF) and the projection matrix method (PROJMAT, Rosenberg et al. 1986, both special and seasonal VBGF) were implemented starting from two seed values sets reflecting the range of values derived by literature, the MPA results and the average of the $L_{\text {max }}$ intervals derived in the present contribute.

The best model was established on the base of the LFDA score function, which measures the goodness of fit of the length frequency distributions for each combination of von Bertalanffy parameters. The higher value of the score function-i.e., the better the goodness of fit - the more consistent that set of von Bertalanffy parameters is with the data.
Given the paucity of data for the species, a comparison with other Mediterranean searobins was performed producing a synoptic table and an auximetric grid (Froese and Pauly 2009) in order to judge the coherence among present and other data. In particular, the synopsis was based on the information gathered from Marano et al. 1999, Voliani et al. 2000, İlhan and Toğulga 2007, Cicek et al. 2008, Boudaya et al. 2008, Froese and Pauly 2009, Ragonese and Bianchini 2010.

\section{RESULTS}

Distribution and abundance. The African armoured searobin occurred thru the whole investigated area, although showing a marked preference for the eastern sector (1). The species was never and occasionally sampled between $10-50 \mathrm{~m}$ and $50-100 \mathrm{~m}$, respectively. The African armoured searobin occurred almost regularly in the outermost shelf edge (100-200 m), and preferentially in the upper slope bottoms $(200-800 \mathrm{~m})$. The highest abundance were observed between 200-500 m ( $f=90 \%$; $\mathrm{DI}=343 ; \mathrm{BI}=22$ ). The temporal evolution of the overall (all strata combined) survey mean Abundance Indexes (DI $=n \cdot \mathrm{km}^{-2}$ and $\mathrm{BI}=\mathrm{kg} \cdot \mathrm{km}^{-2}$ ), for both recovered and registered data (Fig. 2), showed an almost linear and not significant trend $\left(r_{s}=0.04\right.$ and 0.02 for DI and BI, respectively).

The box plot representation of size at different depths (Fig. 3) showed a slight decrease from the shelf break (100-200 m) until $350 \mathrm{~m}$ followed by stability in the deeper waters. Linear interpolation of the median size vs. depth $\left(r_{s}=0.204\right)$ confirmed the lack of any significant depth-size effect.

Sex ratio, size at maturity stages, and maturity condition. The analysis confirmed that sex can be clearly macroscopically distinguishable above 120-140 mm TL. The $S r$ ranged between 0.48 and 0.78 (Pizzicori unpublished*) and 0.38 and 0.81 (original data). The overall estimations resulted 0.54 and 0.49 respectively for grey and direct data (Table 3). In general and when the sample size is large, the $\mathrm{Sr}$ departed slightly from the expected $\mathrm{Sr}$ of 0.5 ; however, differences from 0.5 resulted significant for both the grey $\left(\chi^{2}=20.1\right)$ and the direct estimation (with the exception of 2004 survey). On the contrary, no size effect resulted by analyzing $S r$ vs. size class $\left(r_{s}=0.273\right)$.

As concerns the consistence of different maturity stages, females were $53 \%$ immature, $24 \%$ immature developing or recovering, 9\% maturing, 3\% fully mature, and only $1 \%$ spent or resting. A similar pattern resulted in males: $34 \%$ were immature, $27 \%$ immature developing or recovering, $14 \%$ maturing, $19 \%$ fully mature, and $6 \%$ spent or resting.

As concern the box plot representation of size at different macroscopic stages, in general adult stages (2 to 5) show close medians and higher than the 1st stage (Fig. 4). Slight discrepancy was detected comparing both males and females; in particular, adult male's medians (200-240 $\mathrm{mm})$ were higher than adult females $(200-230 \mathrm{~mm})$. The same phenomenon was detected between juvenile males $(190 \mathrm{~mm})$ and juvenile females $(170 \mathrm{~mm})$. 


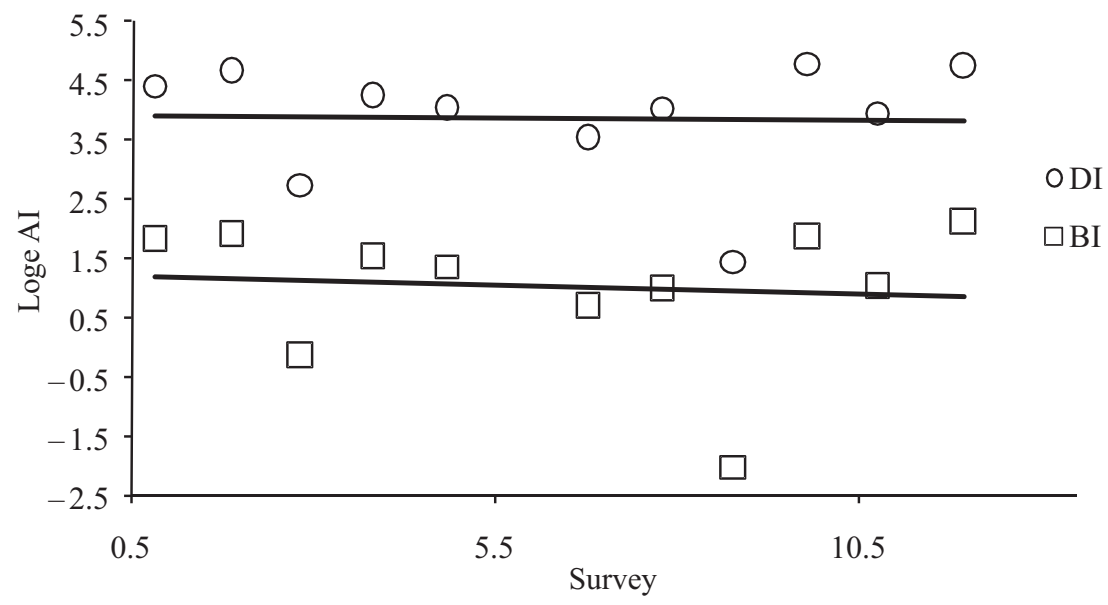

Fig. 2. Overall (all stratum combined) temporal evolution of the survey mean Abundance Indices (DI $=n \cdot \mathrm{km}^{-2}$ and $\mathrm{BI}=\mathrm{kg} \cdot \mathrm{km}^{-2}$ ) of Peristedion cataphractum (after $\log _{\mathrm{e}}$ transformation) from 1994 (0.5 survey time) to 2005 (survey not carried out in 1999)

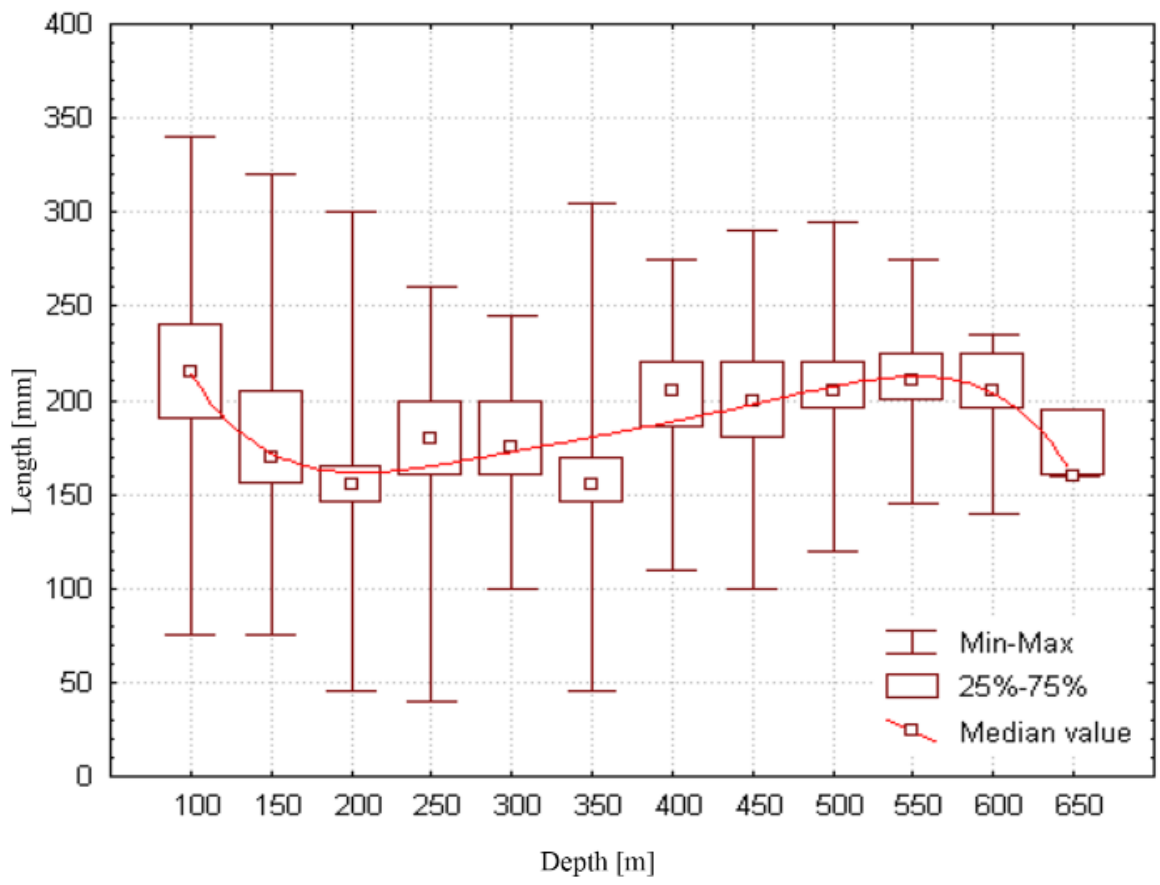

Fig. 3. Overall (all years combined) length (median total length) by depth interval of Peristedion cataphractum

Females and males reached sexual maturity at 191 and $212 \mathrm{~mm}$ (Fig. 5), respectively. A slight precocious maturity in females was observed.

Length frequency distribution, its evolution in time and LFD based growth. The size of the specimens ranged from 40 to $330 \mathrm{~mm}$ TL revealing a LFD shape close to the $\mathrm{C}$ typology proposed by Gulland and Rosenberg (1992): modes well distinguished among the smaller size classes, reflecting discrete recruitment (although not each mode necessarily representing an annual cohort), and then merged at older ages (Fig. 6). Although the typology is maintained between seasonal surveys, it is worth remarking that the recruits component is more evident and completed in spring making autumn surveys less representative of the whole stock structure.
Implementing the FiSAT procedures, $L_{\max }$ estimations fall between 344 and $355 \mathrm{~mm}$ whereas the Bhattacharya analysis allowed the identification of up to 5 modal groups. On the base of the short embryo phase (2-3 days), few months of larval phase (Spartà 1947) and the summer spawning peak reported for the investigated stock (Table 1), the spring modal components around 120-130 mm should correspond to about 7-8 months of age, hence the putative age classes assigned ranged between 0.5 and 4.5 years (Table 4). Size at age fit integrated with the literature data allowed the identification of two sets of seed values for the LFDA procedures, corresponding to a "faster" (310 $\left.L_{\infty} \sim 380 \mathrm{~mm} ; 0.20 \sim K \sim 0.34\right)$ and "slower" (430 L $\sim 470 \mathrm{~mm} ; 0.14 \sim K \sim 0.2$ ) growth scenario.

The LSCA routine resulted in growth performance and index of fit better than those obtained with the 

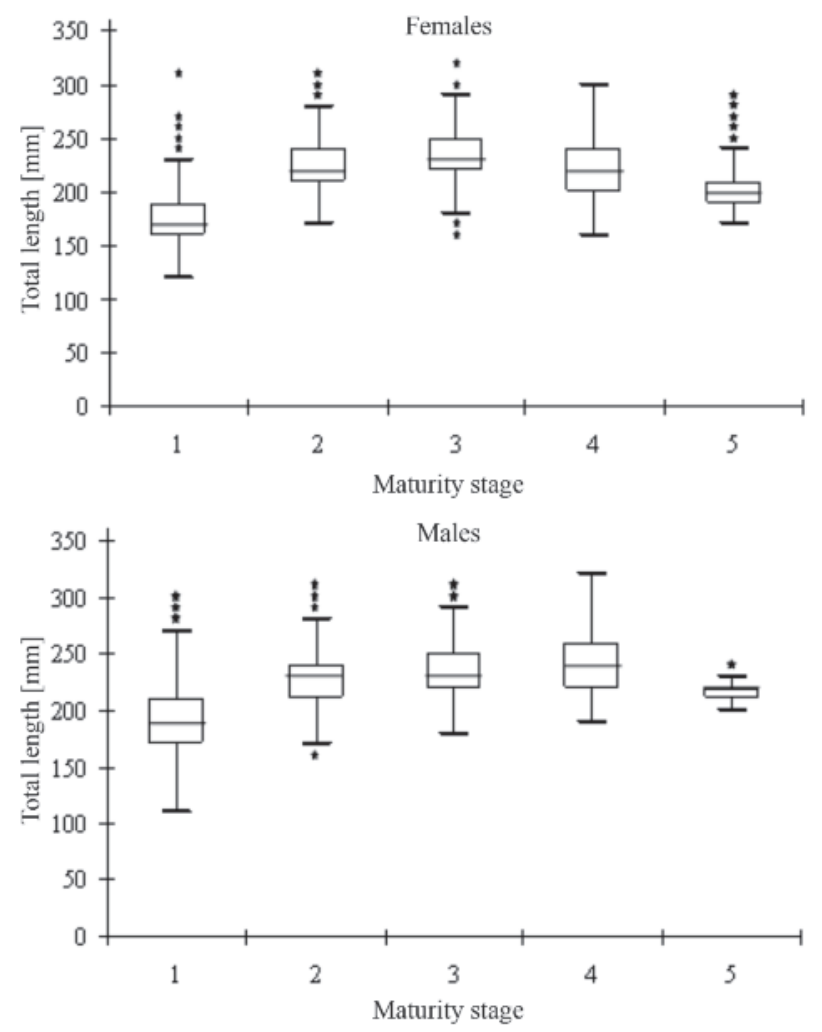

Fig. 4. Overall (years combined) total length structure by maturity stage (according to Holden and Raitt 1974) for females and males of Peristedion cataphractum; Asterisks indicate outliers
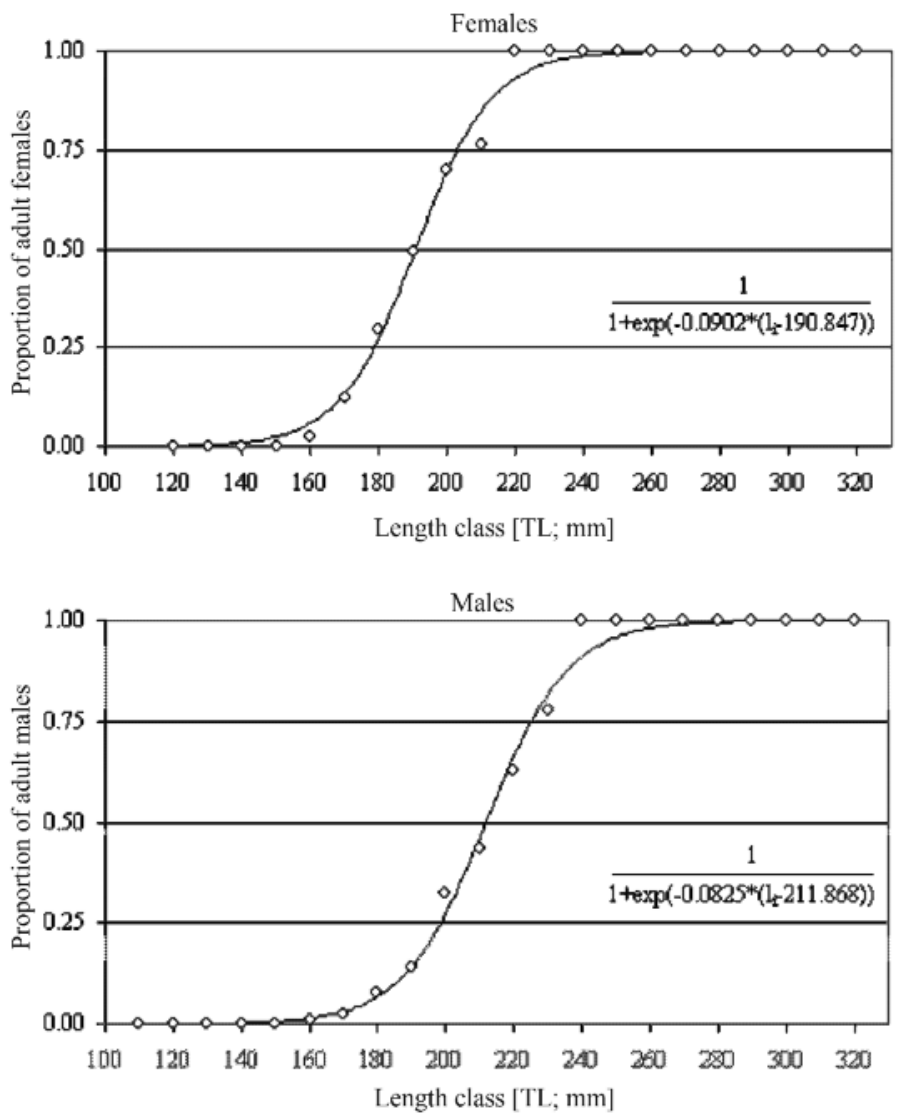

Fig. 5. Overall (years combined) proportions of mature/adults specimens by size class for Peristedion cataphractum females and males with over imposed the logistic fit and corresponding estimated coefficients 
Projmat and Elefan procedures; the LSCA cannot be used for the seasonal version, but Projmat has revealed almost no gain in applying seasonal instead of the classic VBGF. The scores were more or less the same with the complication of more parameters to be included.

Hence the special von Bertalanffy growth function was chosen resulting in estimations of $L_{\infty}=380 \mathrm{~mm}$, $K=0.34$, and $t_{0}=-0.764$ in the 1994-1998 time series and $L_{\infty}=313 \mathrm{~mm}, K=0.285$, and $t_{0}=-0.989$ in the 2000-2005 time series (Fig. 7), the former set showing a score quite higher than the second set (Table 5).

\section{DISCUSSION}

In the presently reported study we have supplied a review of the available data about the distribution, abundance and biological features of a poorly investigated species, $P$. cataphractum in an area of the central Mediterranean Sea.

Although any interpretation of present results is hampered by the temporal discontinuity and sampling variability in data collection and scanty information available for other conspecific stocks, some coherence is still detectable (Table 6). First of all, the vertical distribution between 50 and $800 \mathrm{~m}$ and the preference for the upper slope $(200-500 \mathrm{~m})$ could be considered a characteristic feature of the Mediterranean stocks.

More interesting appear the rarity in some geographical areas and the highly asymmetric horizontal distribution already highlighted by Pizzicori et al. (1995) for the present stock, but also described at least for the Ionian populations (abundant along the Hellas side but rare along the Ionian coasts of Italy; Matarrese et al. 1996, Pizzicori et al. 1995).

Hydrological features do not seem to play a relevant role since the preferential depth range is characterized by a quite homoeothermic condition in Mediterranean Sea.

Table 2

Season and year of the sampling surveys carried out off the southern coasts of Sicily from which Peristedion cataphractum data were recovered (1994-1998) or directly gathered (2000-2005); No survey was carried out in 1999

\begin{tabular}{lcccc}
\hline Season & $\begin{array}{c}\text { Survey } \\
\text { No. }\end{array}$ & Year & $\begin{array}{c}\text { No. of } \\
\text { valid } \\
\text { hauls }\end{array}$ & $\begin{array}{c}\text { No. of } \\
\text { specimens }\end{array}$ \\
\hline Spring & 1 & 1994 & 133 & 653 \\
Autumn & 2 & 1994 & 130 & 854 \\
Spring & 2 & 1995 & 127 & 556 \\
Autumn & 4 & 1995 & 123 & 1253 \\
Autumn & 5 & 1996 & 83 & 160 \\
Autumn & 6 & 1997 & 268 & 1296 \\
Autumn & 7 & 1998 & 266 & 984 \\
Autumn & 8 & 2000 & 86 & 604 \\
Autumn & 9 & 2001 & 92 & 1030 \\
Autumn & 10 & 2002 & 65 & 42 \\
Autumn & 11 & 2003 & 199 & 1464 \\
Autumn & 12 & 2004 & 172 & 609 \\
Autumn & 13 & 2005 & 170 & 2242 \\
\hline
\end{tabular}

Table 3

Sex ratio evolution by time for Peristedion cataphractum, and corresponding $\chi^{2}$ test results

\begin{tabular}{lccccccc} 
Parameter & 2000 & 2001 & 2002 & 2003 & 2004 & 2005 & Total \\
\hline No. of females & 247 & 384 & 29 & 617 & 274 & 1328 & 2879 \\
No. of males & 356 & 637 & 7 & 843 & 299 & 908 & 3050 \\
$S r$ & 0.41 & 0.38 & 0.81 & 0.42 & 0.48 & 0.59 & 0.49 \\
Variance $S r$ & 0.020 & 0.015 & 0.066 & 0.013 & 0.021 & 0.010 & 0.006 \\
$\chi 2$ value & 19.7 & 62.7 & 13.4 & 35.0 & 1.1 & 78.9 & 4.9 \\
$\chi 2$ significance & $*$ & $*$ & $*$ & $*$ & ns & $*$ & $*$ \\
\hline \\
* = statistic significant $\chi^{2}($ at $P<0.05) ; n s=$ not significant; \\
$S r=$ sex ratio.
\end{tabular}

Table 4

Great mean length (mm) at age class (year) of Peristedion cataphractum (sex combined) according to MPA analysis $N$ denotes the number of groups

\begin{tabular}{lccccc}
\hline Age class & 0.5 & 1.5 & 2.5 & 3.5 & 4.5 \\
\hline$N$ & 1 & 6 & 9 & 8 & 4 \\
Great Mean & 105.0 & 149.2 & 192.3 & 230.9 & 261.1 \\
Standard error & - & 5.29 & 3.85 & 3.50 & 7.63 \\
\hline
\end{tabular}

Table 5

Observed (ob) and estimated (es) maximum size $\left(L_{\max }\right)$, and VBGF parameters of Peristedion cataphractum, according to the length frequency distribution analysis (FiSAT and SLCA - LFDA)

\begin{tabular}{lcccccc}
\hline Surveys & $L_{\max }$ ob & $L_{\max }$ es & $\begin{array}{c}L_{\infty} \\
{[\mathrm{mm}]}\end{array}$ & $K_{y}-1$ & $-t_{0_{y}}$ & Score \\
\hline$* 1994-98$ & 330 & 355 & 380 & 0.34 & 0.764 & 59.2 \\
${ }^{\circ} 2000-05$ & 320 & 344 & 313 & 0.285 & 0.989 & 13.1 \\
\hline
\end{tabular}

${ }^{\circ}$ slow growth trajectory;

* fast growth trajectory.

The edaphic factors (Pérès and Picard 1964), via bottom typology and texture, could represent a more likely influencing factor given the specialist feeding pattern of the species, but no specific data exist to corroborate this hypothesis. Instead, fishing intensity could play an important role. As the other large sized triglids, the species appears quite sensible to fishing pressure and the rarity in some areas might reflect the interaction between poor bottom quality and higher fishing intensity. In particular, the old reports (Bourgois and Farina 1961, Arena unpublished*), the fishermen anecdotes (cf. Pizzicori et al. 1995) and the higher catch rates (up 500 specimens and $21 \mathrm{~kg}$ in 1 hour trawling) obtained on the western side of the investigated area in the first surveys realized in 1985 (Pizzicori unpublished ${ }^{* *}$ ) tend to suggest a previous wider horizontal abundance of the species. Further, it is worth noting how the present higher abundance zone on the eastern sector is located next to the Maltese exclusive fishing zone (MEFZ), where bottom trawling is lim- 


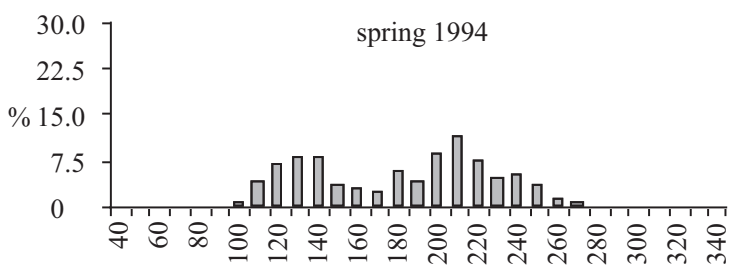

$\mathrm{TL}[\mathrm{mm}]$

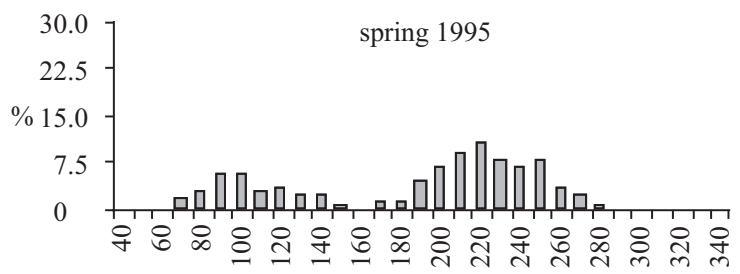

$\mathrm{TL}[\mathrm{mm}]$

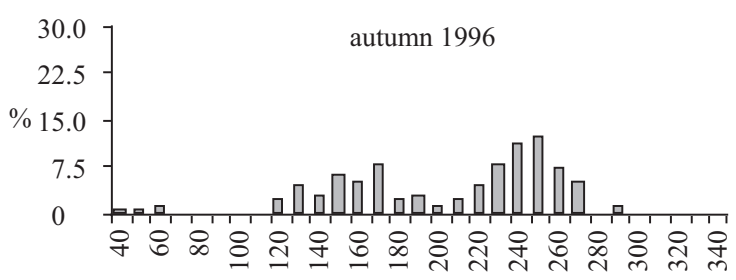

$\mathrm{TL}$ [mm]

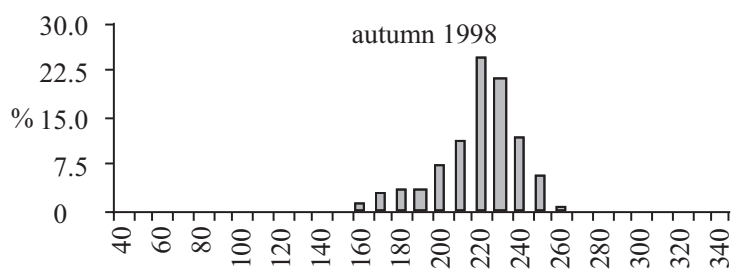

$\mathrm{TL}[\mathrm{mm}]$

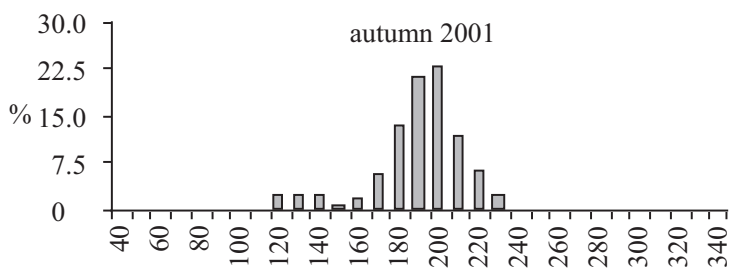

$\mathrm{TL}[\mathrm{mm}]$

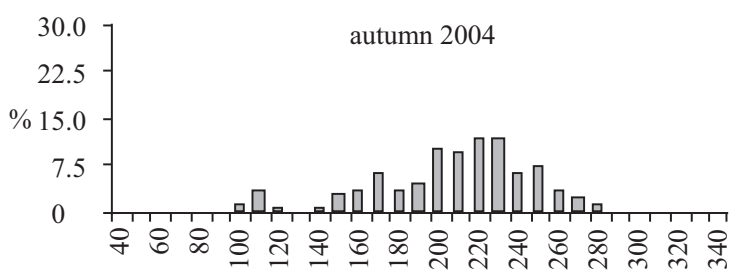

$\mathrm{TL}$ [mm]

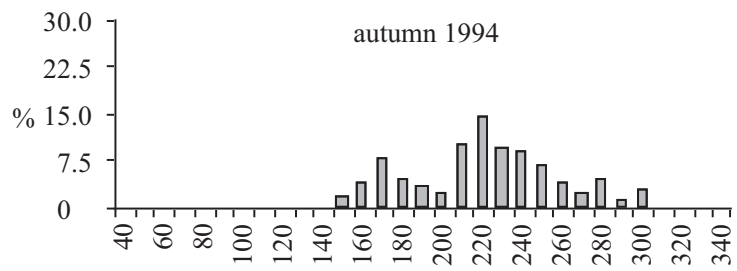

$\mathrm{TL}[\mathrm{mm}]$

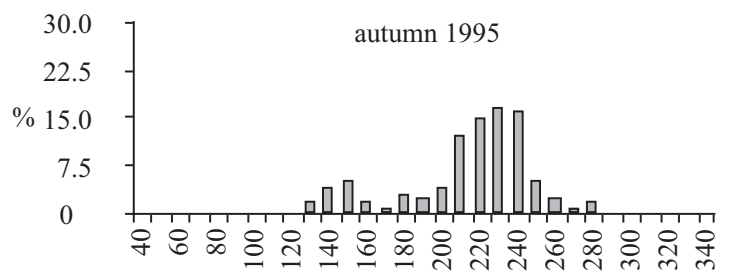

$\mathrm{TL}[\mathrm{mm}]$

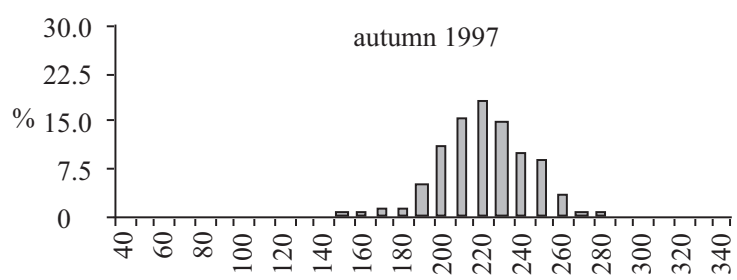

TL [mm]

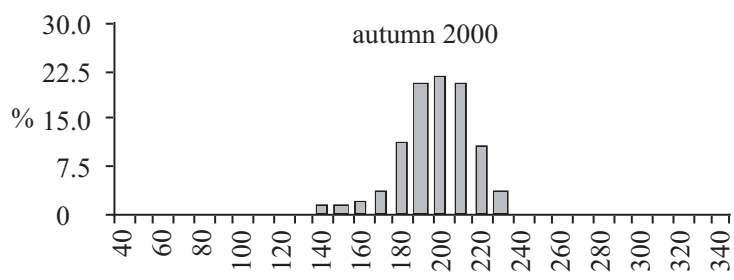

TL [mm]

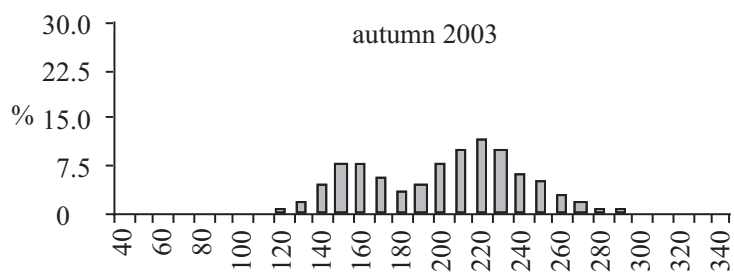

$\mathrm{TL}[\mathrm{mm}]$

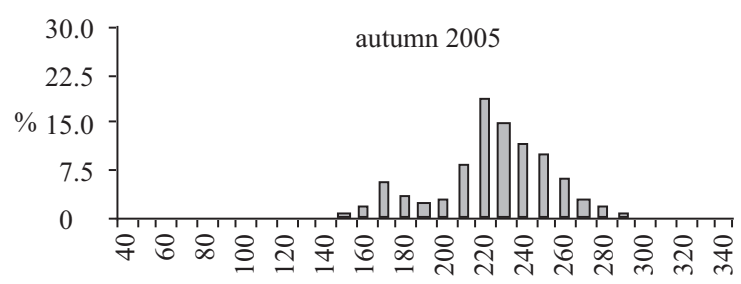

$\mathrm{TL}[\mathrm{mm}]$

Fig. 6. Length frequency distributions by season (all depths) of Peristedion cataphractum (both sexes combined)

ited (or almost nihil) and fishing impact is considered depth range of $200-500 \mathrm{~m}$ although juveniles show less than the contiguous areas (Gristina et al. 2006, a slight preference for the outer shelf and upper slope Dimech et al. 2008). (around 200-300 m; Pizzicori et al. 1995). Similarly to the

As regard the depth vertical distribution and other large sized Mediterranean searobin (Table 6), the depth-length relation, present results tend to confirm that upper and lower depth limits might be individuated around both recruits/juveniles and adults share the preferential 50 and $900 \mathrm{~m}$, respectively. Unfortunately, no specific 

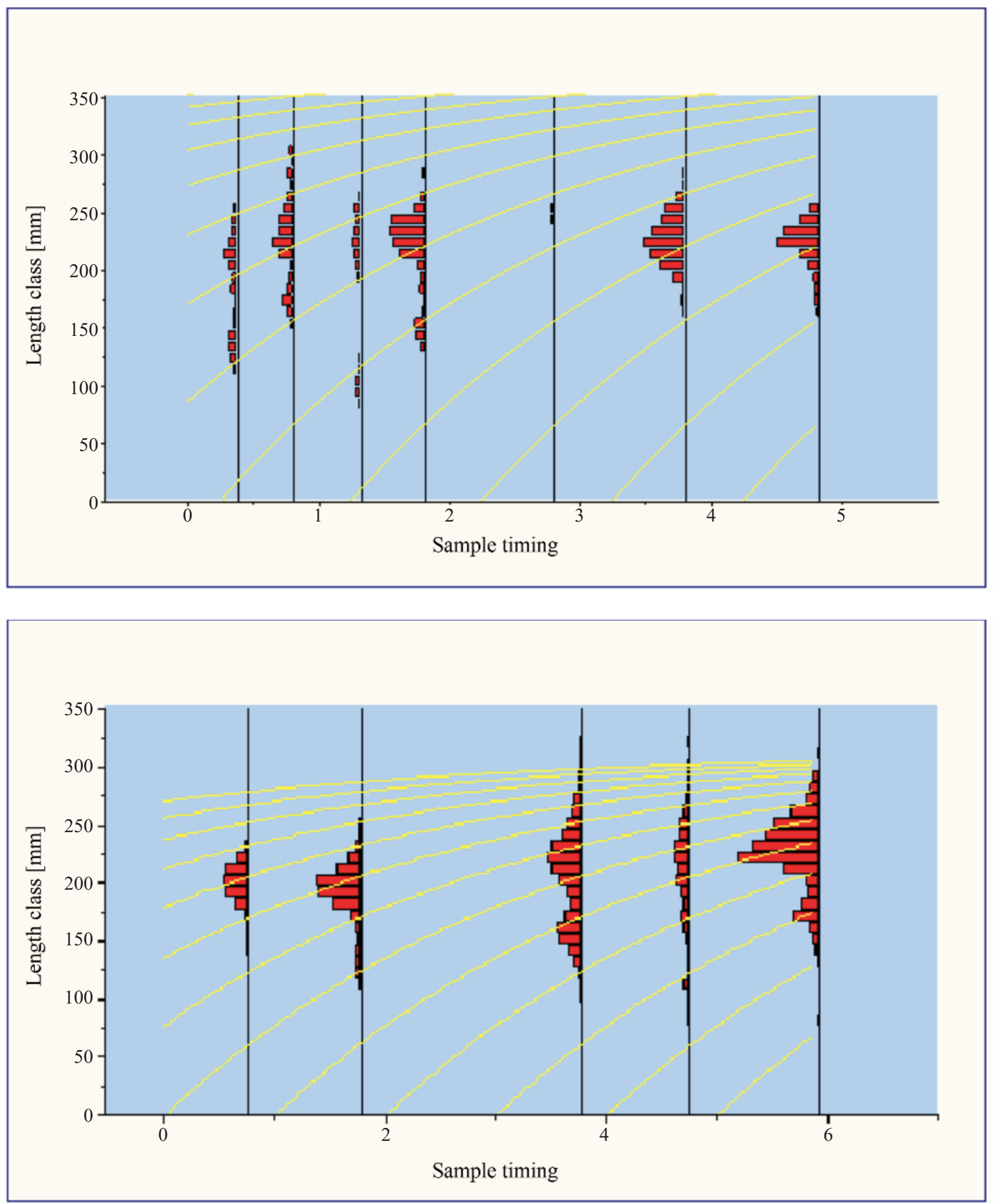

Fig. 7. LFDA 5-VBGF fit plot of Peristedion cataphractum (sex combined) for the more representative (1994-1998; upper side) and adults representative (2000-2005; lower side) time series; The parameters were: $L_{\infty}=380 \mathrm{~mm}$, $K=0.34, t_{0}=-0.764$, and $L_{\infty}=313 \mathrm{~mm}, K=0.285, t_{0}=-0.989$, for upper and lower side, respectively

comparison can be done for the depth-size relation, but among the other searobins it has been reported for 3 species (Chelidonichthys lucernus, C. obscurus and Lepidotrigla cavillone) (Papaconstantinou 1982, Campillo 1992, Colloca et al. 1997, Faltas and Abdallah 1997, Serena et al. 1998, Marano et al. 1999, Voliani et al. 2000, Ceriola et al. 2004, İșmen et al. 2004, Eryılmaz and Meriç 2005,
Uçkun 2005, İlhan and Toğulga 2007, Boudaya et al. 2008, Cicek et al. 2008, Froese and Pauly 2009, Ragonese and Bianchini 2010).

Sexual differentiation represents another matter of discussion, but also for this aspect both grey literature (Pizzicori unpublished*) and published data (Pizzicori et al. 1995, Mytilineou et al. 2004) indicate an overall 
similarity in the morphometric and reproductive features. coefficients ranges, with some effects due to the matching First of all, the sex ratio fluctuates around 0.5 according with the reproductive pattern:

to the season and the location, a pattern quite similar to

a) total vs. rostrum length $(0.888-0.918$ in females and other triglids (Table 6 and Papaconstantinou 1981, 1983). $0.878-0.905$ in males), with only a slight higher slope in Further, neither sex ratio-size relation nor difference in adult females possess a longer rostrum than males at maturity stages have been detected (Pizzicori et al. 1995, a given size (cf. Muñoz Chápuli and Blasco Ruiz 1980); Mytilineou et al. 2004). For the other aspects, Pizzicori b) otolith sagitta length vs. body length $(0.017$ in females (unpublished*) reported quite similar general allometric and 0.016 in males), without sex related differences;

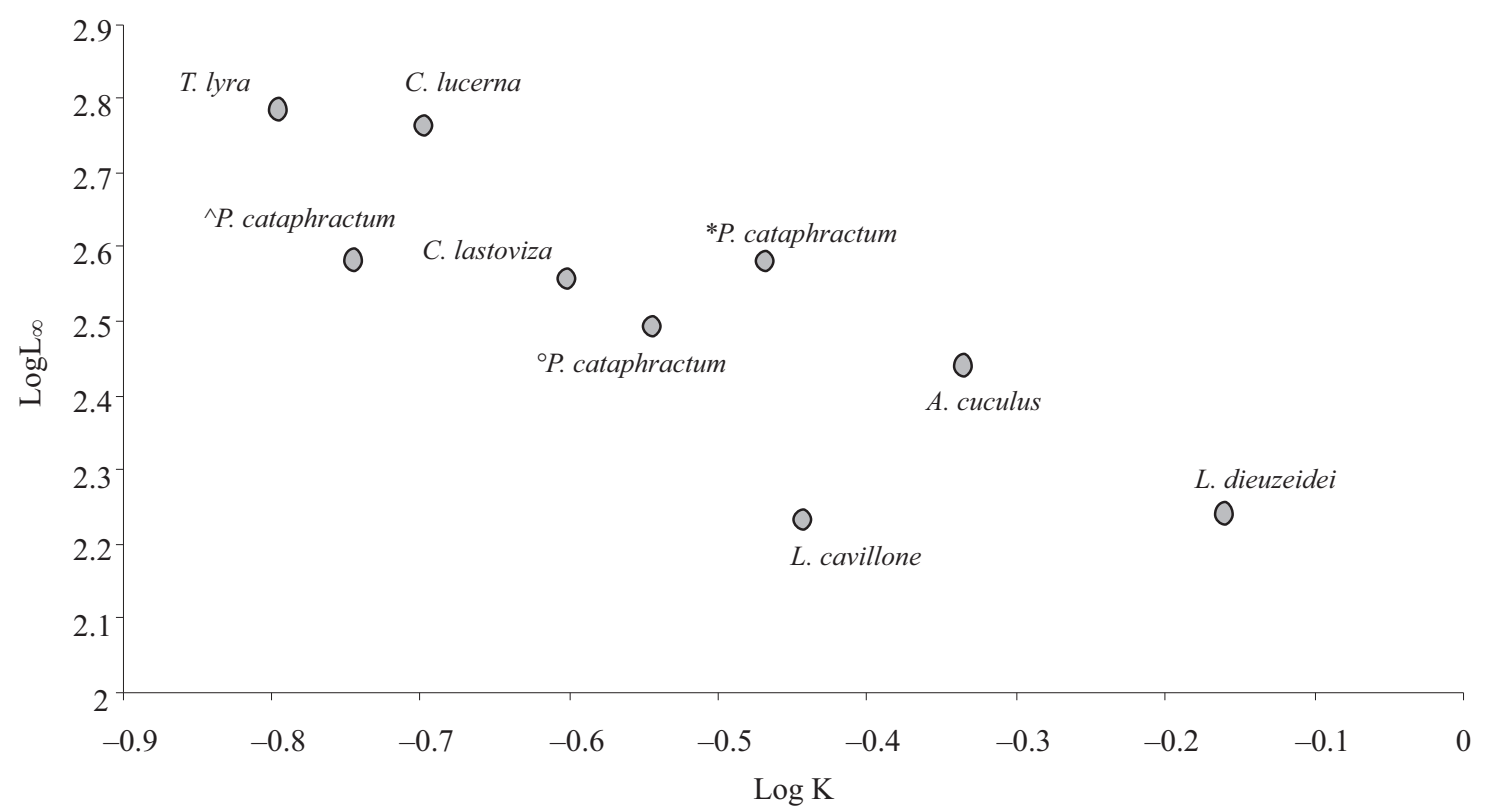

Fig. 8. Auximetric plot (sex combined) to compare Peristedion cataphractum stocks with the other Mediterranean searobins average estimations (see Table 6 for the details) The data for Peristedion cataphractum are from Table $1\left({ }^{\wedge}\right)$ and $5\left({ }^{\circ}=\right.$ slow and $*=$ fast $)$

Table 6

Synopsis of the basic life history features of the Mediterranean searobins stocks

\begin{tabular}{|c|c|c|c|c|c|c|c|c|c|c|c|c|c|c|}
\hline \multirow{2}{*}{ Mediterranean Stocks } & \multicolumn{2}{|c|}{ Depth $[\mathrm{m}]$} & \multirow[b]{2}{*}{ SDr } & \multicolumn{2}{|c|}{ length $[\mathrm{cm}]$} & \multirow{2}{*}{$\begin{array}{c}L m \\
{[\mathrm{~cm}]}\end{array}$} & \multirow{2}{*}{$\mathrm{Sr}$} & \multirow{2}{*}{$\begin{array}{l}\text { Recruitment } \\
\text { Peak }\end{array}$} & \multirow{2}{*}{ SGd } & \multirow[b]{2}{*}{$n$} & \multirow{2}{*}{$\begin{array}{l}L \infty \\
{[\mathrm{cm}]}\end{array}$} & \multirow{2}{*}{$\begin{array}{c}k \\
{[/ y]}\end{array}$} & \multirow{2}{*}{$\begin{array}{c}t_{0} \\
{[\mathrm{y}]}\end{array}$} & \multirow{2}{*}{ References } \\
\hline & range & $\begin{array}{l}\text { usual } \\
\text { max }\end{array}$ & & usual & $\max$ & & & & & & & & & \\
\hline Aspitrigla cuculus (L.) & $15-400$ & 200 & $\mathrm{~N}$ & 25 & 50 & 18 & 1 & $\mathrm{~S}, \mathrm{~A}$ & $\mathrm{~N}$ & 4 & 27.7 & 0.46 & -0.4 & $2,5,13$ \\
\hline $\begin{array}{l}\text { Trigloporus lastoviza } \\
\text { (Bonnaterre, 1788) }\end{array}$ & $20-240$ & 150 & $\mathrm{~N}$ & 20 & 40 & 20 & $1 ;<1$ & $\mathrm{Sp}, \mathrm{S}$ & nd & 3 & 36.2 & 0.25 & -0.9 & $2,8,17$ \\
\hline $\begin{array}{l}\text { Chelidonichthys } \\
\text { lucerna (L.) }\end{array}$ & $50-300$ & 200 & $\mathrm{Y}$ & 50 & 83 & $18-32$ & $1 ;>1$ & A, W, Sp, S & $\mathrm{M}>\mathrm{F}$ & 8 & 58.1 & 0.20 & -1.2 & $\begin{array}{c}1,3,4,7 \\
8,10,11 \\
19,20\end{array}$ \\
\hline $\begin{array}{l}\text { Chelidonichthys obscurus } \\
\text { (Walbaum, 1792) }\end{array}$ & $10-200$ & 150 & $\mathrm{Y}$ & 20 & 40 & 18 & nd & $\mathrm{Sp}-\mathrm{S}$ & nd & & nd & & & 9 \\
\hline Eutrigla gurnardus (L.) & $20-400$ & 200 & $\mathrm{~N}$ & 40 & 60 & $14-24$ & $>1$ & $\mathrm{Sp}, \mathrm{S}, \mathrm{A}$ & $\mathrm{M}>\mathrm{F}$ & & nd & & & 9 \\
\hline $\begin{array}{l}\text { Lepidotrigla cavillone } \\
\text { (Lacepède, 1801) }\end{array}$ & $30-600$ & 200 & $\mathrm{Y}$ & 15 & 20 & $8-12$ & 1 & S, W & $\mathrm{N}$ & 7 & 17.3 & 0.27 & -1.5 & $\begin{array}{l}2,5,12 \\
15,18,21\end{array}$ \\
\hline $\begin{array}{l}\text { Lepidotrigla dieuzeidei } \\
\text { Blanc et Hureau, } 1973\end{array}$ & $30-600$ & 200 & $\mathrm{~N}$ & 15 & 20 & 12 & nd & $\mathrm{S}$ & $\mathrm{N}$ & 1 & 17.5 & 0.69 & -0 & 21 \\
\hline Trigla lyra L. & $50-700$ & 500 & $\mathrm{~N}$ & 40 & 60 & $25-30$ & $1 ;<1$ & $\mathrm{~S}, \mathrm{~A}$ & $\mathrm{~N}$ & 3 & 61.2 & 0.16 & -1.0 & $2,14,15$ \\
\hline
\end{tabular}

$\mathrm{SDr}=$ size-depth relations; $\mathrm{N}=$ not; $\mathrm{Y}=$ yes; $L_{\mathrm{max}}=$ maximum sizes; $L_{\mathrm{m}}=$ size at sexual maturity; $S r=\operatorname{sex}$ ratio $(F /$ total $)$; $\mathrm{Sp}=$ Spring; $\mathrm{S}=$ Summer; $\mathrm{A}=$ Autumn; $\mathrm{W}=$ Winter; $\mathrm{SGd}=$ sex related growth rate differential; $\mathrm{M}=$ males; $\mathrm{F}=$ females; nd $=$ no data; $n=$ of VBGF set used; $L_{\infty}, K$, and $t_{0}$ average of the VBGF; Valid fish names according to Froese and Pauly (2009) (may differ from those in cited references) References: 1 = Boudaya et al. 2008; 2 = Campillo 1992; $3=$ Ceriola et al. 2004; 4 = Cicek et al. 2008; 5 = Colloca et al. 1997; 6 = Colloca et al. 2003; 7 = Eryılmaz L., Meriç 2005; 8 = Faltas and Abdallah 1997; $9=$ Froese and Pauly 2009; $10=$ İlhan and Toğulga 2007; 11 = İsmen et al. 2004; $12=$ Marano et al. 1999; $13=$ Marsan et al. 1998; 14 = Papaconstantinou, 1981; 15 = Papaconstantinou 1982; 16 = Papaconstantinou 1983; 17 = Papaconstantinou 1986; 18 = Ragonese and Bianchini 2010; 19 = Serena et al. 1998; 20 = Uçkun 2005; 21 = Voliani et al. 2000. 
c) whole body weigth-ungutted weight (0.842-0.920 in females and 0.912-0.942 in males), with a lower somatic weight in females only in summer, a phenomenon already described by Baron (1985) for Trigla lucerna;

d) length-weight relations (3.090-3.423 in females, 3.064-3.274 in males and 2.684-3.095 in indeterminate) with again a seasonal effect in adult females which show a better condition in spring summer.

The seasonal effect in the condition is maintained also considering the relation derived on sex combined. The range of the $b$ allometric coefficient, in fact, was higher in spring-summer (3.050-3.297) than autumn-winter (2.812-3.160) surveys. That seasonal fluctuation might explain the slight variation among published parameters: 2.970 and 3.030 for the north Aegean (Filiz and Bilge 2004) and the Balearic Islands (Merella et al. 1997), respectively.

All these features along with the seasonal evolution of the gonadosomatic index (in females; Pizzicori et al. 1995) and consistence of the different macroscopic maturity stages (in both sexes; Pizzicori et al. 1995, Mytilineou et al. 2004) are in agreement with a prolonged maturing/ripening period, and a spawning peak occurring in spring-summer or summer-autumn depending on local slight variation in population dynamic.

The logistic approach has evidenced a slight precocious maturity in females $\left(L_{m}=191 \mathrm{~mm}\right)$ than males $\left(L_{m}=212 \mathrm{~mm}\right)$, maybe the only result in contrast with the general pattern observed in triglids (Papaconstantinou 1984, Baron 1985, McPhail et al. 2001, Boudaya et al. 2008). However, this size differential in the African armoured searobin would correspond to less than 1 year of age on the base of the average lengths at 2-3 years observed by Pizzicori et al. (1995) (185-225 mm; LBMs) and Mytilineou et al. (2004) (176-213 mm; otholits readings).

Regarding present VBGF estimations, it remains the problem of the detected differences between the two data sets analyzed. Given that the methodology employed is the same, it is likely that the differential fit reflects the differences in the samples in particular the fact that the more recent autumn surveys do not cover the season where the recruitment component is well defined and completed. Consequently, the 1994-1998 estimations are likely more representative as also supported by the high score, similarity with the asymptic size in Mytilineou et al. (2004) estimations and coherence with the other searobins (Fig. 8). Which can be the interpretation of the lower $L_{\infty}$ and $K$ estimations obtained in the 2000-2005 data sets? A plausible explanation can be derived from the theoretical approach resumed in Stamps et al. (1998), which consider the whole growth curve of a given iteroparous and long living stock as the resultant of two growth trajectory, the juvenile (with higher $L_{\infty}$ and $K$ ) and the adults (with lower $L_{\infty}$ and $K$ ), whereas the achievement of sexual maturity represent the discriminant factor or discontinuity element. This approach might explain some of the most recurrent problematic in growth estimation among which the discrepancy between the asymptotic and maximum ever recorded (or estimated) length. In the present study, for example, these figures were:
313-380 $\left(L_{\infty}\right), 344-355$ (estimated $\left.L_{\max }\right)$, and $400\left(L_{\text {max }}\right.$ ever $)$ $\mathrm{mm}$. According to the Stamps approach, the largest very rare specimens of Peristedion records (400 $\mathrm{mm}$ ) may represent fish which have delayed or even skipped the achievement of sexual maturity maintain for longer time the juvenile curve trajectory. Further, recent evidences have shown that occasional omission (skipping) of spawning in females may occur more frequently than previously believed (cf. Livingston et al. 1997) also representing an adaptive trait in long living iteroparous fishes (Rideout et al. 2005).

Present review of the available data on Peristedion cataphractum allows the suggestion of a plausible life history for Peristedion cataphractum as follows: eggs are spawned from May to October; small sized recruits (40-100 mm) occur continuously from September to March, but the recruitment peak (i.e., youngest of the year, YOY, component) is from late December through March (80-130 mm), a season unfortunately rarely or marginally covered by the Sicilian surveys. The YOY grow up to $170-200 \mathrm{~mm}$ in summer followed by the other two pulses which tend to merge in summer at about 150-160 $\mathrm{mm}$ and $110-130 \mathrm{~mm}$, respectively, following the juvenile's growth trajectory. On the contrary, the medium and large sized maturing and mature specimens begin to follow the adult's trajectory and tend to pile up in the second preeminent component with modal length comprised between 200-220 mm. According to the biological or structural variability of the different surveys, the second component may appear as one single or twothree overlapping minor components and this pattern may explain the VBGF differential between the two set of data resulting in higher growth rate and asymptotic size when YOY were sampled and the opposite when adults represent the main component. Synthetically, the growth rate remains high $\left(70-60 \mathrm{~mm} \cdot\right.$ year $\left.^{-1}\right)$ till $1.5-2$ years of age, decreasing once sexual maturity is started and sexual maturity achieved between 190-210 mm of length $\left(L_{m}\right)$, around 2-3 years of age (adults trajectory).

Although preliminary, it is worth noting how this growth pattern appears quite coherent with the general high plastic life history and average growth patterns of the Mediterranean searobins, which likely reflects the necessity to "match" the spawning and recruitment phases with the best period of the preferred food availability (Colloca et al. 2003).

\section{REFERENCES}

Baron J. 1985. Les triglides (Téléostéens, Scorpaeniformes) de la Baie de Douarnenez. I. La croissance de: Eutrigla gurnardus, Trigla lucerna, Trigloporus lastoviza et Aspitrigla cuculus. Cybium 9 (2): 127-144.

Bauchot M.L., Pras A. 1980. Guide des poissons marins d'Europe. Delachaux et Niestlé, Paris.

Bhattacharya C.G. 1967. A simple method of resolution of a distribution into Gaussian components. Biometrics 2: 115-135.

Bini G. 1969. Atlante dei pesci delle coste italiane. Vol. 4. Osteitti. [Atlas of the Italian coast of fish. Vol. 4. Osteichthyes.] Mondo Sommerso Editrice, Rome. [In Italian.] 
Boudarel N. 1948. Les richesses de la mer. Pp. 359-360. In: Lechevalier P. (ed.) Technologie biologique et océanographique. Encyclopédie Biologique. Vol. 29.

Boudaya L., Neifair P., Rizzo P., Badalucco C., Bouain A., Fiorentino F. 2008. Growth and reproduction of Chelidonichthys lucerna (Linnaeus) (Pisces: Triglidae) in the Gulf of Gabès, Tunisia. Journal of Applied Ichthyology 24 (5): 581-588. DOI: 10.1111/j.1439-0426.2008.01095.x.

Bourgois F., Farina L.F. 1961. Essais de chalutage au large des côtes tunisiennes. FAO/EPTA, Raport No. 1410.

Briand F. 2000. The Eastern Mediterranean climatic transient, its origin, evolution and impact on the ecosystem. Workshop Series CIESM, Monaco, No. 10.

Campillo A. 1992. Les pêcheries françaises de Méditeranée: synthèse des connaissances. Institut Francais de Recherche pour l'Exploitation de la Mer, France.

http://archimer.ifremer.fr/doc/1992/rapport-1125.pdf.

Ceriola L., Marano C.A., Martino M., Marzano M.C., Ungaro N. 2004. Informazioni preliminari sull'accrescimento di Trigla lucerna Linnaeus, 1758 nell'Adriatico meridionale. [Preliminary information on growth of Trigla lucerna Linnaeus, 1758 in the southern Adriatic.] Biologia Marina Mediterranea 11 (1): 163-165. [In Italian.]

Cicek E., Avsar D., Ozyurt C.E., Yeldan H., Manasirli M. 2008. Age, growth, reproduction and mortality of tub gurnard Chelidonichthys lucernus (Linnaeus, 1758)) inhabiting in Babadillimani bight (northeastern Mediterranean coast of Turkey). Journal of Biological Sciences 8 (1): 155-160. DOI: 10.3923/jbs.2008.155.160.

Colloca F., Cardinale M., Ardizzone G.D. 1997. Biology, spatial distribution and population dynamics of Lepidotrigla cavillone (Pisces: Triglidae) in the central Tyrrhenian Sea. Fisheries Research 32 (1): 21-32.

DOI: 10.1016/S0165-7836(97)00041-6.

Colloca F., Cardinale M., Marcello A., Ardizzone G.D. 2003. Tracing the life history of red gurnard (Aspitrigla cuculus) using validated otolith annual rings. Journal of Applied Ichthyology 19 (1): 1-9.

DOI: 10.1046/j.1439-0426.2003.00342.x.

Dimech M., Camilleri M., Hiddink J.G., Kaiser M.J., Ragonese S., Schembri P.J. 2008. Differences in demersal community structure and biomass size spectra within and outside the Maltese Fishery Management Zone (FMZ). Scientia Marina 72 (4): 669-682.

DOI: $10.3989 /$ scimar.2008.72n4669.

Doderlein P. 1879. Manuale ittiologico del Mediterraneo ossia sinossi metodica delle varie specie di pesci riscontrate sin qui nel Mediterraneo ed in particolare nei mari di Sicilia. [Ichthyological manual of the Mediterranean that is methodological synopsis of the various species of fish hitherto found in the Mediterranean and in particular in the seas of Sicily.] Tipografia del Giornale di Sicilia, Palermo. [In Italian.]

Emery C. 1886. Contribuzioni all'ittiologia. XVII. Larva di genere ignoto.. Mittheilungen aus der Zoologischen Station zu Neapel 6: 162. [In Italian.]

Faltas S.N., Abdallah M. 1997. Growth, mortality and relative yield per recruit of two triglid species from the Egyptian
Mediterranean, off Alexandria. Bulletin of the National Institute of Oceanography and Fisheries 23: 473-484.

Filiz H., Bilge G. 2004. Length-weight relationships of 24 fish species from the North Aegean Sea, Turkey. Journal of Applied Ichthyology 20 (5): 431-432. DOI: $10.1111 /$ j.1439-0426.2004.00582.x.

Formacion S.P., Rongo J.M., Sambilay V.C. 1991. Extreme value theory applied to the statistical distribution of the largest lengths of fish. Asian Fisheries Science 4 (2): 122-135.

Francis R.I.C.C. 1995. The analysis of otolith data-a mathematician's perspective (What precisely is your model?). Pp. 81-95. In: Secor D.H., Dean J.M., Campana S.E. (eds.) Recent developments in fish otolith research. The Belle W. Baruch Library in Marine Science No. 19, University of South Carolina Press, Columbia, SC.

Froese R., Pauly D. (eds.) 2009. FishBase. [Accessed 5 September 2009]. http://www.fishbase.org.

Gayanilo F.C., Sparre P., Pauly D. 2005. FAO-ICLARM Stock assessment tools II (FiSAT II). Revised version. User's Guide FAO Computerized Information Series (Fisheries) No. 8.

Gristina M., Bahri T., Fiorentino F., Garofalo G. 2006. Comparison of demersal fish assemblages in three areas of the Strait of Sicily under different trawling pressure. Fisheries Research 81 (1): 60-71.

DOI: $10.1016 /$ j.fishres.2006.05.010.

Gulland J.A., Rosenberg A.A. 1992. A review of length-based approaches to assessing fish stock. FAO Fisheries Technical Paper No. 323.

Gunderson D.R. 1993. Surveys of fisheries resources. John Wiley and Sons, New York.

Heemstra P.C. 1975. Peristediidae. Pp 489-490. In: Smith M.M., Heemstra P.C. (eds.) Smith's Sea Fishes, SpringerVerlag, Berlin,

Hoenig J.M., Hanumara R.C. 1982. A statistical study of a seasonal growth model for fishes. University of Rhode Island, Department of Computer Science, Technical Report, Narragansett.

Hoggarth D.D., Abeyasekera S., Arthur R.I., Beddington J.R., Burn R.W., Halls A.S., Kirkwood G.P., McAllister M., Medley P., Mees C.C., Parkes G.B., Pilling G.M, Wakeford R.C, Welcomme R.L. 2006. Stock assessment for fishery management - A framework guide to the stock assessment tools of the Fisheries Management Science Programme. FAO Fisheries Technical Paper No. 487 Rome, FAO.

Holden M.J., Raitt D.F.S. 1974. Manual of fisheries science. Part 2. Methods of resources investigation and their application. FAO Fisheries Technical Paper No. 115

Hureau J.C. 1986. Peristediidae. Pp. 1239-1240. In: Whitehead P.J.P., Bauchot M.L., Hureau J.C., Nielsen J., Tortonese E. (eds.), Fishes of the north-eastern Atlantic and the Mediterranean. Vol. 3. UNESCO, Paris.

İlhan (Uçkun) D., Toğulga M. 2007. Age, growth and reproduction of tub gurnard Chelidonichthys lucernus Linnaeus, 1758 (Osteichthtyes: Triglidae) from İzmir Bay, Aegean Sea, Eastern Mediterranean. Acta Adriatica 48 (2): 173-184.

İşmen A., İşmen P., Başusta N. 2004 Age, growth and reproduction of tub gurnard (Chelidonichthys lucerna L. 1758) 
in the Bay of İskenderun in the eastern Mediterranean. Turkish Journal of Veterinary and Animal Sciences 28 (2): 289-295.

Lekshmy Nair A., Prabhu P.V., Vasanth Shenoy A. 1989. Fish sauce from two species of unexploited deep sea fish: Peristedion adenii and Peristedion weberi. Fishery Technology, India 26 (2): 15-31.

Levi D., Ragonese S., Andreoli M.G., Norrito G., Rizzo P., Giusto G.B., Gancitano S., Sinacori G., Bono G., Garofalo G., Cannizzaro L. 1998. Sintesi delle ricerche sulle risorse demersali dello Stretto di Sicilia (Mediterraneo centrale) negli anni 1985-1997 svolte nell'ambito della legge 41/82. [Synthesis of the researchs on demersal resources of the Strait of Sicily (Central Mediterranean) from 1985 to 1997 whitin the law 41/82.] Biologia Marina Mediterranea 5 (3): 130-139. [In Italian.]

Livingston M.E., Vignaux M., Schofield K.A. 1997. Estimating the annual proportion of nonspawning adults in New Zealand hoki, Macruronus novaezelandiae. Fishery Bullettin 95 (1): 99-113.

Marano C.A., Marsan R., Marzano M.C., Ungaro N. 1999. Note sull'accrescimento di Lepidotrigla cavillone (Lacepède, 1802)—Osteichthyes, Triglidae-nelle acque del Basso Adriatico. [About growth of Lepidotrigla cavillone (Lacepède, 1802) - Osteichthyes, Triglidae - in the south Adriatic Sea.] Biologia Marina Mediterranea 6 (1): 584-586. [In Italian.]

Marsan R., Ungano N., Marzano M.C., Martino M. 1998. Accrescimento di Aspitrigla cuculus (Osteichthyes, Triglidae) nell'area adriatica sub-occidentale: risultati preliminari. [Growth of Aspitrigla cuculus (Osteichthyes, Triglidae) in the south-western Adriatic area: preliminary results.] Biologia Marina Mediterranea 5 (1): 694-696. [In Italian.]

Matarrese A., D’Onghia G., Tursi A., Basanisi M.1996. New information on ichthyofauna of the south-eastern italian coasts (Ionian sea). Cybium 20 (2): 197-211.

McPhail A.S., Shipton T.A., Sauer W.H.H., Leslie R.W. 2001. Aspects of the biology of cape gurnard, Chelidonichthys capensis (Scorpaeniformes: Triglidae) on the Agulhas Bank, South Africa. Vie et Milieu 51 (4): 217-227.

Merella P., Quetglas A., Alemany F., Carbonell A. 1997. Length-weight relationship of fishes and cephalopods from the Balearic Islands (western Mediterranean). Naga ICLARM Q 20 (3/4): 66-68.

Muñoz Chápuli R., Blasco Ruiz M. 1980. Dinámica del crecimento en Peristedion cataphractum L. Boletin de la Real Sociedad Española de Historia Natural 78 (3-4): 347-353.

Dinamica del crecimiento en Peristedion cataphractum L.

Myers P., Espinosa R., Parr C.S., Jones T., Hammond G.S., Dewey T.A. 2008. The Animal Diversity Web. http://animaldiversity.ummz.umich.edu/site/index.html [Accessed 12 November 2009].

Mytilineou C., Christidis G., Terrats A., Kavadas S. 2004. Preliminary results on the biology of Peristedion cataphractum (L., 1758) in the eastern Ionian Sea. Rapport de la Commission Internationale pour l'exploration scientifique de la mer Méditerranée 37: 408.
Papaconstantinou C. 1981. Age and growth of piper, Trigla lyra, in Saronikos Gulf (Greece). Cybium 5 (2): 73-87.

Papaconstantinou C. 1982. Epi tīs viologias tou eidous Lepidotrigla cavillone (Oikogeneia Triglidae) tōn Ellinikōn thalassōn. [On the biology of the Lepidotrigla cavillone (Family Triglidae) of the Greek Seas.] Thalassographica 5 (1): 33-59. [In Greek.]

Papaconstantinou C. 1983. Epi tīs viologias tou eidous Aspitrigla cuculus (L., 1758) (Pisces: Scorpaeniformes) sto Sarōniko Kolpo. [On the biology of Aspitrigla cuculus (L., 1758) (Pisces: Scorpaeniformes) in the Saronikos Gulf.] Thalassographica 6: 49-75. [In Greek.]

Papaconstantinou C. 1984. Age and growth of the yellow gurdard (Trigla lucerna L. 1758) from the Thermaikos Gulf (Greece) with some comments on its biology. Fisheries Research 2 (4): 243-255. DOI: 10.1016/0165-7836(84)90028-6.

Papaconstantinou C. 1986 The life history of rock gurnard (Trigloporus lastoviza Brünn. 1768) in the Saronikos Gulf. Journal of Applied Ichthyology 2 (2): 75-86. DOI: $10.1111 / \mathrm{j} .1439-0426.1986 . t b 00432 . x$.

Pauly D. 1984. Fish population dynamics in tropical waters: a manual for use with programmable calculators. ICLARM Studies and Reviews No. 8. International Center For Living Aquatic Resources Management Manila, Philippines.

Pérès J.M., Picard J. 1964. Nouveau manuel de bionomie benthique de la Mer Mediterranée. Recueil des Travaux de la Station Marine d'Endoume 47 (31): 5-137.

Pizzicori P., Ragonese S., Rizzo P. 1995. Sulla distribuzione e biologia del pesce forca, Peristedion cataphractum L. 1758 (Peristadidae) nello Stretto di Sicilia (Mediterraneo Centrale). [Distribution and biology of the African armoured searobin Peristedion cataphractum in the Strait of Sicily.] Biologia Marina Mediterranea 2 (2): 287-293]. [In Italian.]

Quignard J.P., Tomasini J.A. 2000. Mediterranean fish biodiversity. Biologia Marina Mediterranea 7 (3): 1-66.

Ragonese S., Bianchini M.L. 2010. Historical growth and mortality 'benchmark' values of Lepidotrigla cavillone (PiscesTriglidae) in the Strait of Sicily (Mediterranean Sea). Journal of Applied Ichthyology 26 (1): 113-115. DOI: 10.1111/j.1439-0426.2009.01372.x.

Ragonese S., Nardone G., Gancitano S., De Santi A., Ottonello D., Jereb P. 2008. Seawater temperature records gathered during experimental bottom trawl surveys in the Strait of Sicily (Mediterranean Sea). Naturalista Siciliano 32 (3-4): 3-18.

Rideout R.M., Rose G.A., Burton M.P.M. 2005. Skipped spawning in female iteroparous fishes. Fish and Fisheries 6 (1): 50-72. DOI: 10.1111/j.1467-2679.2005.00174.x.

Rosenberg A.A., Beddington J.R. 1988. Length-based methods of fish stock assessment. Pp. 83-103. In: Gulland J.A. (ed.) Fish population dynamics. 2nd edn. John Wiley and Sons, Chichester, UK.

Rosenberg A.A., Beddington J.R., Basson M. 1986. The growth and longevity of krill during the first decade of pelagic whaling. Nature 324 (6093): 152-154.

DOI: $10.1038 / 324152 \mathrm{a} 0$. 
Sardà F., Calafat A., Flexas M.M., Tselepides A., Canals M., Tortonese E. 1975. Osteichthyes (Pesci Ossei). [Osteichthyes Espino M, Tursi A. 2004. An introduction to Mediterranean deep-sea biology. Scientia Marina 66 (Suppl. 3): 7-38. (bony fishes).] Vol. 11. Parte 2. Edizioni Calderini, Bologna. [In Italian.]

Serena F., Voliani A., Auteri R. 1998 Nursery areas and some biological information of tub gurnard (Trigla lucerna L. 1758) off Tuscany coasts (Italy). Rapport de la Commission Internationale pour l'exploration scientifique de la mer Méditerranée 35 (1): 482-483.

Sheperd J.G. 1987. A weakly parametric method for estimating growth parameters from length composition data. Pp. 113-120. In: Pauly D., Morgan G.R. (eds.) Length-based methods in fisheries research. ICLARM Conference Proceedings 13, International Center for Living Aquatic Resources Management, Manila, Philippines and Kuwait Institute for Scientific Research, Safat, Kuwait.

Spartà A. 1947. Rilievi su stadi attribuiti a Myctophum gemellari Cocco e periodo di maturità sessuale, uova, stadi embrionali e post embrionali di Peristedion cataphractum. [Observations on Myctophum gemellari Cocco and on the period of sexual maturity, eggs, embryonic and post-embryonic stages of Peristedion cataphractum.] Bollettino Pesca Piscicoltura Idrobiologia 23 (2): 5-12. [In Italian.]

Stamps J.A., Mangel M., Phillips J.A. 1998. A new look at relationships between size at maturity and asymptotic size. American Naturalist 152 (3): 470-479.

Received: 12 January 2010

Accepted: 23 March 2010

Published electronically: 15 December 2010 (Kırlangıç Balıkları)'na Ait Türlerin Yaş ve Büyüme Özelliklerinin İncelenmesi. [Investigation of the age and growth characteristics of the species belonging to the family Triglidae in Edremit Bay.] Journal of Fisheries and Aquatic Sciences 22 (3-4): 363-369. [In Turkish.]

Voliani A., Mannini P., Auteri R. 2000. Distribuzione e biologia di Lepidotrigla cavillone (Lacepede) e L. dieuzeidei (Audoin in Blanc and Hureau) nell'Arcipelago Toscano. [Distribution and biology of Lepidotrigla cavillone (Lacepede) and L. dieuzeidei (Audoin in Blanc and HUREAU) in the Tuscan Archipelago.] Biologia Marina Mediterranea 7 (1): 844-849. [In Italian.] 